\title{
OBRIGADO!
}

\section{MEMÓRIA E MEMORIAL DE UM SOCIÓLOGO DO DIREITO'}

Luciano Oliveira ${ }^{\mathrm{i}}$

$\mathrm{N}$ asci numa cidade chamada Itabaiana. Não a da Paraíba, terra do sanfoneiro Sivuca. A minha é de Sergipe, o menor estado da federação, terra de Sylvio Romero e de Tobias Barreto, que também passaram por aqui... E eu, quem sou e como aqui cheguei? Como a sociologia jurídica tornou-se preponderante na minha identidade como pesquisador e professor? Nada foi calculado; quase tudo foi fruto de uma série de acasos felizes. É preciso, então, que eu diga algo sobre mim e a minha carreira de sortudo!

Acrescento que não tenho um nome importante, nem poderoso, embora meu pai fosse um dos comerciantes considerados "ricos" na minha Itabira. Nunca teve gado nem fazendas, mas tinha uma farmácia, herdada do seu pai. Minha mãe, essa, tinha origens na roça, e seu pai chegou a ter gado e fazenda. Mas, com a idade avançando, torrou tudo nos cobres para vir morar na cidade. Homem de um tempo morto, era de guardar seus cobres perto de si, e eles foram roídos pela inflação. Morreu quase pobre, com as filhas "costurando para fora" para sobreviver. Minha mãe, ao se casar com meu pai, tornou-se o que se chamava uma mulher do lar, ajudando o marido no comércio e tomando conta da casa e de nós. Na época, não se falava

${ }^{i}$ Este texto reproduz quase integralmente a minha fala de agradecimento à homenagem que, por iniciativa (e trabalheira) do professor Artur Stamford da Faculdade de Direito do Recife, foi-me prestada na ocasião do IV Congresso da Associação Brasileira de Pesquisadores em Sociologia do Direito (ABrasD), realizado em Recife, nos dias 11, 12 e 13 de novembro de 2013. A Artur, pela alegria que me deu, devo mais, bem mais, do que um Obrigado! 
em dupla, tripla jornada de trabalho, mas era isso. Pai distante, mãe resignada - como era comum naquele tempo. Como veem, nada de excepcional. Diferentemente do herói (ou antiherói...) de Machado de Assis, nunca meu pai, orgulhoso, ergueu-me no ar vaticinando um futuro radioso: "Um Cubas! Um Cubas!"

Talvez deva dizer, já que aquilo em que me tornei foi possível pelo meu amor aos livros com quem sempre vivi agarrado -, que talvez a explicação para essa minha "vocação" resida no fato de ter sido neto do meu avô paterno, Florival de Oliveira - aquele de quem meu pai herdou a farmácia -, que foi uma porção de coisas na vida: farmacêutico, rábula, promotor, inspetor escolar, e que conheci já velho, aposentado, eternamente de pijama e lendo sem parar. Lia de tudo, do melhor e do pior. Na biblioteca enorme que deixou encontrei de Dante Alighieri a Karl May, um alemão autor de romances populares de faroeste, hoje justamente esquecido. Digo que foi importante porque aquela figura velha e bonita (fisicamente ele lembrava Mário Lago), que todos reverenciavam e chamavam de "Doutor Florival", funcionou como um modelo com quem quis me identificar.

Minha formação educacional foi a mais convencional do mundo em famílias interioranas como a minha. O primário e o ginásio em Itabaiana, e o clássico em Aracaju. É assim que era dividido o estudo na época. Depois de terminado o ginásio, havia o científico para os que queriam fazer medicina, química, engenharia, e o clássico, para quem ia para direito, serviço social etc. Eu ainda comecei o científico e, por incrível que pareça, até que não era mau em física! Mas como gostava mesmo era de literatura, mudei para o clássico. Isso foi no Colégio Estadual de Sergipe (espécie de Ginásio Pernambucano de lá) o qual, embora público, era o que de melhor havia em Sergipe. O ginásio, como disse, foi em Itabaiana mesmo. Findo o clássico, fiz direito sem maior convicção, provavelmente porque era um curso de prestígio. Como avaliá-lo? As lembranças que eu tenho dessa época são acima de tudo lembranças afetivas de um tempo em que eu e meu grupo de amigos fazíamos, como estudantes, uma tímida resistência ao regime militar: jornal mural, panfletos, essas coisas. Uma vida de estudante meio boêmia... aquelas cervejadas que entravam madrugada adentro quando os mais afoitos começavam a cantar "Pra não dizer que não falei de flores" de Geraldo Vandré. Acreditem: isso já foi proibido no Brasil.

Sobre o curso que fiz, uma impressão geral que tenho da faculdade daquele tempo é a de que era uma espécie de clube inglês, onde os "sócios" iam de manhã dar aulas e, entre uma e outra, ficavam batendo papo, fazendo fofoca e discutindo os processos que os ocupariam no verdadeiro trabalho, à tarde, no fórum. Eram quase todos juízes, desembargadores, promotores e advogados bem sucedidos, para os quais certamente os vencimentos como professor não importavam e tinham aquilo mais como um título de prestígio e um hobby do que propriamente como uma profissão.

Aos trancos e barrancos, formei-me em 1976. Era bacharel em ciências jurídicas e sociais. A experiência como advogado, isto é, como advogado liberal, foi péssima. Eu realmente não tinha vocação para aquilo. Aquele ambiente de fórum, "ilustre colega" pra cá, "grande jurista” pra lá, aquele negócio de "data venia" o tempo todo, não dava para mim. Mas deixando de lado esse problema de temperamento, havia também uma coisa muito desagradável, perversa mesmo, que era aquela promiscuidade entre ofício público e remuneração privada, herança dos tempos em que os cargos públicos eram explorados por particulares, o que fazia com que o advogado, isto é, a parte, tivesse de pagar as citações e diligências diretamente ao funcionário da justiça. Havia as tabelas oficiais, lógico, mas ninguém dava bola para aquilo. Então, para fazer uma citação, o oficial vinha com aquela conversa tipicamente brasileira, "Doutor, o homem mora longe, vou ter que pegar um taxi..." Era a institucionalização da corrupção. Não sei hoje em dia como andam essas coisas. Espero que tenham melhorado. Ademais, independentemente disso havia também minha própria dificuldade em ter um comportamento de profissional liberal. Saber cobrar um preço pelo meu trabalho, por exemplo, sempre tive uma dificuldade insuperável em fazer isso.

Mas, por incrível que pareça, àquela altura eu 
tinha me tornado um razoável profissional de direito. Como? Para falar a verdade, eu sempre fui um mau aluno. Mas no último ano e meio de curso eu até que aprendi bastante direito, não na faculdade, mas num estágio que fiz na assessoria jurídica do Banco do Nordeste. Foi lá que aprendi alguma coisa. A princípio o trabalho dos estagiários era ler o diário oficial para acompanhar as ações de interesse do banco e fazer pesquisa doutrinária e jurisprudencial para municiar os advogados nas petições e pareceres. Aos poucos, como sempre gostei dessa coisa de pesquisar e escrever, comecei a construir arrazoados que acompanhavam o material que tinha pesquisado. Daí a pouco eu estava fazendo minutas de pareceres, e depois, os próprios pareceres! Em resumo, me tornei um razoável parecerista. Mas o ano (era o ano de 1976) terminou, e com ele acabou-se o que era doce. Formei-me e me vi sem estágio, obrigado a me virar como advogado.

Como era comum naquele tempo para quem, como eu, não tinha uma família com banca instalada na praça, juntei-me a alguns colegas que já tinham um escritório. Aí era o que aparecesse: usucapião, inventário, desquite... até cobrança de cheque sem fundo! Só do crime não me ocupava. A ideia de fazer um júri, por exemplo, nunca me passou pela cabeça. Na verdade, faltava-me vocação e ânimo para investir naquela carreira. Andava chateado, até pensando em abandonar simplesmente o direito, fazer um concurso público em qualquer coisa, Caixa Econômica, Banco do Brasil, Petrobrás... qualquer coisa.

Quando, um belo dia, um ex-colega de faculdade me procurou em casa convidandome para ir trabalhar com ele numa repartição da Secretaria de Indústria e Comércio do Estado de Sergipe. Fiquei até surpreso, porque ele tinha sido um daqueles alunos bem certinhos, de saber os prazos recursais na ponta da língua (o que então se chamava de C.D.F.), enquanto eu pertencia ao grupo dos "esquerdistas", que nada queriam com o direito. Foi o pessoal do Banco do Nordeste quem lhe recomendou o meu nome. Não pensei duas vezes. Afinal, o novo trabalho, além de me assegurar uma remuneração boa e certa, era o tipo de advocacia que eu, se não amava, pelo menos suportava: elaborar contratos, dar pareceres etc. Isso foi num domingo. Já na segunda informei aos meus sócios minha decisão de deixar o escritório. Foi ótimo para todo mundo. Algum tempo depois o colega que me convidara afastouse da Secretaria para ser promotor público e eisme promovido ao cargo que era seu: o de assessor jurídico do órgão. Nisso passei os anos de 1978 e 1979. Até que, em 1980, larguei tudo e vim para o Recife, fazer um mestrado.

Mas por que decidi largar uma vida que estava tão arrumadinha na burocracia do Estado de Sergipe e partir para um novo destino? Simplificando bastante, eu estava um tanto farto de viver elaborando pareceres que terminavam sempre com a fórmula clássica: "salvo melhor juízo". Na faculdade nós tínhamos inquietações intelectuais e políticas que iam além do direito. Refiro-me ao grupo de contestadores a que eu pertencia. Evidentemente, éramos todos marxistas. Era um marxismo de manual, mas tudo bem. Então eu diria que a tendência intelectual mais natural para quem era marxista não era o direito, mas a sociologia. A minha intenção, justamente, era fazer um mestrado em sociologia e voltar para ingressar na universidade nessa área, não na área do direito. Tanto que, quando vim embora, pedi uma licença para tratar de interesses particulares sem remuneração. Fui viver de bolsa e de umas economias que tinha feito, justamente já pensando nisso.

O meu mestrado não foi em direito, mas em sociologia. A definição por sociologia foi feita conscientemente por mim. Mas a especificidade, isto é, sociologia jurídica, ou do direito, se vocês preferirem, foi um golpe de sorte - mais um na minha vida.

Acontece que o mestrado para onde fui tinha uma área de concentração em sociologia jurídica. Isso porque havia lá, na época, dois sociólogos do direito muito importantes: Cláudio Souto e Joaquim Falcão. Mas eu não sabia de nada disso. $\mathrm{O}$ que eu conhecia de sociologia era, repito, marxismo. Praticamente só. Talvez eu já tivesse ouvido falar muito vagamente em nomes como Weber e Durkheim, mas nada conhecia deles. E o que eu pretendia fazer, ao vir para cá, era aplicar o marxismo ao direito, como se estivesse 
inventando algo novo, imaginem. De sociologia jurídica eu não sabia nada.

$\mathrm{E}$ aí encontro os dois. $\mathrm{E}$ os dois eram a sociologia jurídica recifense. E sem dúvida o que de melhor havia em termos de sociologia jurídica no Brasil. Cláudio era um nome famoso. Pensando na disciplina em termos de pesquisa empírica, era praticamente o seu fundador no Brasil. Já no começo dos anos 60, ele havia feito pesquisas empíricas para subsidiar uma legislação estadual sobre reforma agrária. Aí veio o fatídico ano de 1964 e seu trabalho de sociólogo reformador foi interrompido. Mas Cláudio, que era socialista cristão (não sei se ainda é socialista; cristão, certamente!), sempre teve uma vocação para a teoria sociológica e terminou assumindo essa vocação e voltando-se para temas como sentimento e ideia de justiça, encarados numa perspectiva bem teórico-formal. Ele sempre foi preocupado em construir uma teoria mais geral sobre o direito, a justiça e o próprio social. Para um marxista como eu, era tudo muito abstrato. Já Joaquim trabalhava com coisas mais próximas de minhas preocupações. $\mathrm{Na}$ época ele pesquisava conflitos entre proprietários de terras e invasores urbanos no Recife. Essa coisa que num país como o Brasil continua atualíssima. Ele estava interessado em ver como o judiciário, os proprietários, os ocupantes e o Estado agiam nessas ocasiões. Quais as estratégias jurídicas para resolver, nos marcos de um direito civil e processual privatístico, conflitos que eram coletivos?

Terminei afinando-me intelectualmente mais com Joaquim. O mais engraçado é que, de início, o meu orientador era Cláudio. Como eu não conhecia nenhum dos dois quando cheguei, o coordenador do mestrado, ex-officio, designou Cláudio como meu orientador. Mas, com o passar do tempo, eu comecei a ver que o meu negócio era mais com Joaquim e Cláudio também sentiu isso. Tanto que, num determinado momento, muito elegantemente, deixou-me completamente à vontade para mudar de orientador, se quisesse. Eu quis. E fui ser orientando de Joaquim.

Virei "menino de Joaquim". Que era uma pessoa muito dinâmica e empreendedora. Vivia viajando, e eu comecei a dar aulas de sociologia a seus alunos de direito nas suas ausências. Ele também tinha fundado um grupo de trabalho na ANPOCS (Associação Nacional de PósGraduação e Pesquisa em Ciências Sociais). O grupo se chamava Direito e Sociedade, e reunia gente de todo o país. O pessoal de Warat em Santa Catarina, o pessoal de José Eduardo Faria em São Paulo, o pessoal de Roberto Lyra Filho em Brasília, tinha também Miranda Rosa do Rio de Janeiro - e por aí vai, ou ia...

Em 1981, no meu segundo ano no Recife, Joaquim me leva para uma dessas reuniões e, como seu mandato de coordenador estava terminando, indica-me seu sucessor! Todo mundo, lógico, votou no meu nome e eu, um ilustríssimo desconhecido, tornei-me uma alta autoridade nas instâncias institucionais da sociologia jurídica brasileira - mais num lance de sorte! Já estava de bom tamanho, não? Mas tem mais.

Quando vim para o Recife, a minha intenção era passar aqui apenas dois anos. Pelos meus cálculos, era o tempo suficiente para fazer os créditos, fazer a pesquisa e voltar para escrever a tese em Aracaju. Só que, algum tempo antes de escoar-se o prazo, Joaquim tinha sido convidado pela Fundação Joaquim Nabuco para fundar um Departamento de Ciência Política, e ficou nas duas instituições, a Universidade e a Fundaj. E aí, quando eu já estava fazendo minha pesquisa de campo e até me preparando para voltar para Aracaju, ele me convidou para ir trabalhar com ele na Fundação. Entre lisonjeado e temeroso, aceitei. E foi assim que me radiquei "definitivamente" no Recife.

Joaquim tinha formado um time dele. Éramos eu, Alexandrina Moura e Affonso Pereira. Os dois últimos também tinham formação jurídica e tinham trabalhado com ele na pesquisa sobre invasões urbanas. Ou seja: o Departamento de Ciência Política terminou tendo, na prática, um perfil preponderante de Departamento de Sociologia Jurídica. Logo depois Alexandrina foi para os Estados Unidos fazer um doutorado com David Trubek e ficamos, eu e Affonso, tocando as pesquisas sociojurídicas.

O que dizer dessa "escola pernambucana" da sociologia jurídica - como uma vez um 
pesquisador a descreveu? É sempre um tanto complicado falar em "escola". Nesse caso, os trabalhos dos seus supostos integrantes eram muito diferentes. Entre mim e Cláudio, por exemplo, há diferenças significativas. Como talvez saibam, a dissertação de mestrado que acabei fazendo foi sobre práticas judiciárias exercitadas por comissários de polícia no Recife, resolvendo pequenos casos das classes populares sem acesso ao judiciário oficial. A tese se chamou Sua Excelência o Comissário, e é até hoje o meu trabalho mais conhecido. Fiz o que os antropólogos chamam de uma etnografia desses julgamentos, descrevendo as partes, seus argumentos, a linguagem por eles utilizada etc. Para Cláudio, sempre interessado em leis gerais do social, tudo isso é muito pouco rigoroso em termos científicos. O que não impede que tenhamos tido e tenhamos até hoje valiosas relações pessoais. Eu nutro por ele um sentimento próximo do afeto filial, que deve ser recíproco, aliás. Mas, em termos de paradigmas, eu com meu marxismo, ele com seu cristianismo, estávamos bem distantes um do outro. Como eu costumo brincar com ele, "nossos santos são diferentes".

Mas e a "escola recifense", finalmente, existiu? Eu acho que é possível dizer que sim, se abstrairmos as diversas orientações substantivas das pessoas que a fizeram e atentarmos para um aspecto, digamos, procedimental, pelo qual é possível nos aproximar numa mesma tendência: a busca de uma base empírica para o nosso trabalho. Eu posso dizer que isso nos distinguia, por exemplo, de Santa Catarina, com o movimento "crítica do direito", de inspiração marxista, e nomes então reluzentes como o de Michel Miaille, Althusser e outros, os quais, via Santa Catarina, entraram no mundo da crítica jurídica brasileira. O movimento do sul fazia uma crítica de certa forma radical ao direito, mas uma crítica teórica, sem contato com a pesquisa empírica, coisa que era vista (mal vista, na verdade) como "empiricismo".

Eu sei que estou simplificando, ma non troppo! Porque essa perspectiva "crítica" analisava o direito em termos de fetichismo, procurando desnudá-lo. Ora, nesse caso, trabalhos como o de Joaquim, vendo nas ocupações uma forma de aquisição da propriedade, ou o meu, onde se trata do problema do acesso à justiça, são trabalhos que, digamos assim, rendem-se ao fetichismo do direito. Eu, até por minha formação marxista, tinha consciência sim dessa dimensão profundamente ideológica do direito. E ainda tenho, aliás. Mas e daí? Pode-se viver fora da ideologia? Como disse o próprio Althusser no seu famosíssimo Aparelhos Ideológicos de Estado, a ideologia é eterna!

Mas, se é assim, passar a vida toda desnudando-a termina sendo um exercício repetitivo, monótono, óbvio e... inútil! Além disso, termina-se ficando só no que Althusser chamava de "trabalho teórico". Não se mete a mão na massa. Termina sendo um bom álibi para não se fazer pesquisa empírica, que dá muito mais trabalho. Pois então. Enquanto o pessoal lá em Santa Catarina lia Miaille, Althusser, Barthes e outros, Joaquim (que tinha e me emprestou o livro de Miaille, aliás) passou-me de preferência autores americanos como Laura Nader, Donald Black, David Trubek. Tudo "empiricista"! Mas também foi por meio dele que conheci o trabalho de Boaventura Santos, um autor marxista, mas que tinha feito uma pesquisa empírica numa favela do Rio de Janeiro estudando um sistema jurídico local operado pela associação de moradores, a que ele deu o nome de "direito de Pasárgada", e que, depois, tornou-se a maior referência teórica da sociologia jurídica brasileira dos anos 80. Bem, a escola pernambucana de sociologia jurídica, se existiu, era isso que a caracterizava: o pejorativamente chamado "desvio empiricista".

Mas volto à Fundaj e à equipe que então formamos - sobretudo, com a ida de Alexandrina para os Estados Unidos, eu e Affonso Pereira. Findo o meu trabalho sobre os comissários, trabalhamos juntos em uma pesquisa sobre conflitos coletivos e acesso ao judiciário. Dela resultou um livro, Conflitos Coletivos $e$ Acesso à Justiça, editado pela própria Fundaj com o patrocínio da OAB-PE, que passou completamente despercebido. A pesquisa tinha algo da perspectiva daquela de Joaquim sobre as invasões - ou, como se diz hoje, ocupações. $\mathrm{Ou}$ seja: conflitos coletivos para os quais o sistema 
jurídico, estribado em bases privatísticas, não tinha respostas satisfatórias. Só que dessa vez eram temas ideologicamente menos quentes, digamos. Nós pegamos dois tipos de conflito, ecológicos e de consumidores, e fomos verificar a adequação ou não do direito processual para resolvê-los.

Lógico que verificamos a inadequação. Mas, para chegar a essa verificação, construímos uma tipologia de conflitos baseada nas suas características reais: quais eram os mais numerosos, quem eram os infratores, quantas pessoas estavam envolvidas como vítimas etc. $\mathrm{E}$ aí nos deparamos com dados que nos levavam a certas conclusões interessantes. Por exemplo: a teoria clássica da responsabilidade civil, baseada na solvência do devedor, não serve para tratar o conflito ecológico porque, hoje em dia, com os processos produtivos potencialmente danosos que temos, qualquer fabriqueta cujos bens valham, digamos, 500 mil reais, pode despejar uma porcaria num rio e causar um dano a $500 \mathrm{mil}$ pessoas! Mesmo que seus donos sejam pessoas honestas e queiram pagar o prejuízo (hipótese apenas para argumentar, como se sabe...), eles não poderão fazê-lo. Então tem que se pensar em controle prévio das atividades industriais, em processos administrativos abertos às associações ecológicas e de consumidores para intervir no procedimento de licenciamento da atividade, por exemplo. E também na representação judicial por intermédio dessas associações e do Ministério Público.

Lógico, a pesquisa está datada. Ela foi feita em 1984, e desde então houve mudanças processuais no sentido da necessidade que tínhamos detectado, inclusive a Lei da Ação Civil Pública. Mas isso é só para dar um exemplo do tipo de trabalho que fazíamos, e também para mostrar ao jurista o tipo de trabalho que lhe pode servir, que eventualmente ele mesmo pode fazer. Não se trata de nenhuma pesquisa sociológica sofisticada, com métodos avançados de sociologia. É mais um aporte de dados sociológicos a um trabalho que é, em sua essência, jurídico, destinado a finalidades práticas. Seria ótimo que os juristas adotassem posturas desse tipo, incorporassem algo da démarche sociológica, no sentido de uma argumentação baseada em dados demonstráveis, deixando de lado aquela forma de discutir baseada em argumentos de autoridade do tipo "como preleciona magistralmente o insigne..." e por aí vai.

Vejam bem: não é transformar o direito numa ciência social. Eu francamente não acredito nisso. Mas é que o direito no Brasil continua sendo tratado com base nessa forma prémoderna de argumentar, onde os autores são ícones. Eu ainda me lembro do meu professor de Introdução à Ciência do Direito, que se referia ao autor do nosso código civil como "sábio e santo, santo e sábio Clóvis Bevilácqua”... Ele mesmo, e isso sem nenhuma intenção irônica, tratava Tobias Barreto de "Himalaia da cultura jurídica brasileira”! É evidente que não está em discussão nem a sabedoria de Clóvis nem a cultura jurídica de Tobias. Mas tratá-los de santo, de Himalaia... Essa não é uma questão meramente estilística, vejam bem. No caso (como sempre, aliás), o estilo é portador de um conteúdo. Eu acho que essa nossa retórica, onde todo mundo é benfeitor da humanidade, tem a ver com algo mais profundo na formação brasileira. A nossa história é toda feita de conciliações superficiais que mascaram e não resolvem os nossos conflitos fundamentais. Nós temos horror do confronto. De alto a baixo. Todo mundo é amigo de todo mundo e ninguém critica ninguém. Fala mal, mas pelas costas, o que é outra coisa. Na cara, não, até porque aqui se confunde crítica com ofensa pessoal.

Mas avancemos um pouco porque, como dizia Cazuza, o tempo não para! Da Fundaj fui para a França, fazer meu doutorado, que não foi em ciência política. Foi, formalmente falando, outra vez em sociologia. Só que o meu orientador, Claude Lefort, nunca foi sociólogo. Que eu saiba, nunca fez uma pesquisa sociológica na vida. Era (porque já faleceu) um filósofo da política, e a minha tese de doutorado, que não deixa de ter uma parte sociológica, acho que seria melhor classificá-la como sendo em filosofia política. Mas por que Lefort como orientador?

Antes é preciso que eu diga que a minha tese foi sobre os direitos humanos e o pensamento político de esquerda no Brasil. Como já disse, eu vinha de uma formação basicamente marxista. 
Ora, dentro dessa tradição, o direito é uma superestrutura ideológica destinada, aliás, a desaparecer um dia numa sociedade comunista reconciliada, onde todo mundo vai viver fraternalmente. Nesse caso, a reflexão sobre o direito é mais uma reflexão contra o direito. E os direitos humanos entram de roldão nessa crítica. Ora, mesmo tendo vindo fazer o mestrado no Recife com a ideia muito vaga de analisar o direito a partir do marxismo, eu comecei a alimentar uma pulga atrás da orelha assim que comecei a ler, a sério, sobre o assunto. Porque nós, nós que vivemos sob a ditadura militar, sabemos muito bem a importância prática que tem o respeito aos direitos humanos, porque nós vimos, e alguns de nós até sentiu na pele, o que é viver num regime que os desrespeita. Explico-me.

No longínquo ano de 1976, ano em que me formei, passei uma semana de horror, com medo de ser preso e torturado para confessar sabe lá Deus o quê! Oito dias antes do carnaval daquele ano, no fim da tarde de uma inesquecível sextafeira, alguns colegas da faculdade e conhecidos dos meios políticos e sindicais começaram a "desaparecer". Passaram pelo calvário hoje em dia tão conhecido: incomunicabilidade, capuz e choque elétrico. Tinham sido presos pelas forças de segurança do regime militar que já começava a se desagregar, mas ainda tinha força e ferocidade bastantes para tais ignomínias. Todos eles foram torturados durante um longo, longuíssimo, fim de semana nas dependências do $28^{\circ}$ Batalhão de Caçadores sediado em Aracaju. Quando reapareceram, todos tinham marcas de tortura. (Um deles, Milton Coelho da Graça, sindicalista da Petrobrás, ficou cego como sequela dessas torturas.)

Ora, já no Recife, fazendo o meu mestrado, quando comecei a ler mais sistematicamente o que o marxismo dizia sobre o direito, comecei a achar que suas análises eram insuficientes. Foi quando li Marx a sério, e até flertei com a ideia de fazer uma tese teórica sobre essa questão, ideia que não levei adiante - desincentivado, aliás, pelo próprio Joaquim, que sempre investiu numa sociologia de base empírica, como terminou sendo o caso da minha dissertação de mestrado sobre Sua Excelência o Comissário. Mas a intenção de fazer um trabalho sobre marxismo e direitos humanos ficou sempre gotejando na minha cabeça.

Vai daí que, um dia, já concluído o mestrado e procurando ideias para o doutorado, li um texto de Claude Lefort, "Direitos do Homem e Política”, que na época, naquele momento de reinvenção da democracia entre nós, foi muito lido no Brasil. Quando li o texto, tomei um choque. Lefort fazia uma leitura crítica da crítica marxista do direito e dizia coisas que eu também tinha pensado. Pronto, a escolha estava feita. O resto foi incrivelmente fácil. Escrevi-lhe uma carta expondo genericamente o que queria fazer, consultando-o sobre a possibilidade de ser meu orientador. Ele prontamente respondeu, aceitando-me. E fui fazer meu doutorado. Em setembro de 1986, eu e minha pequena família Bebé, então minha esposa, e nossa filhinha Júlia - partimos para a França.

Em $1^{\circ}$ de abril de 1991, desembarquei no aeroporto dos Guararapes com a tese defendida. Ela se chama Imagens da Democracia, e tem por subtítulo: Os direitos humanos e o pensamento político de esquerda no Brasil. Passei um tempão procurando publicá-la numa grande editora. Não consegui. A Brasiliense, depois de muitas idas e vindas, encomendou-me um trabalho menor. Lá publiquei, em 1994, um livrozinho pela coleção Tudo é História, chamado Do Nunca Mais ao Eterno Retorno - Uma reflexão sobre a tortura, reeditado em 2009. A tese, terminei publicando-a numa pequena editora recifense, que nem existe mais, praticamente uma edição do autor. A circulação, claro, foi muito restrita. Nela faço uma análise de como o tema dos direitos humanos, inexistente e até menosprezado como ideologia pequeno-burguesa na cultura política marxista, passa a ser incorporado pelo pensamento político de esquerda depois do choque que foram as brutais violações desses direitos durante o regime militar.

Devolta do doutorado, reintegrei-meà Fundaj, mas o núcleo informal de sociologia jurídica que tínhamos ali tinha praticamente desaparecido. Joaquim Falcão, seu fundador, há muito tempo tinha deixado a Fundaj e o Recife, indo estabelecer-se definitivamente no Rio de Janeiro, 
de onde era oriundo. Alexandrina Moura, que tinha assumido a chefia do Departamento em seu lugar, terminou assumindo um perfil de cientista política. E Affonso Pereira, meu companheiro de pesquisas, que se havia tornado meu amigo mais íntimo, tinha simplesmente abandonado a pesquisa! Assumiu cargos administrativos na Fundaj e fez um percurso inverso ao meu: voltou ao direito. Explicando sua decisão, certa vez ele me disse: "O sociólogo quer transformar o mundo, mas não transforma. $\mathrm{O}$ juiz não quer transformar o mundo, mas transforma alguma coisa quando dá uma sentença”. Eu brinco com ele, dizendo que isso é um álibi que ele inventou para justificar sua deserção. Mas reconheço que tem uma boa dose de verdade no que ele diz. O diabo é que a sentença de um juiz pode também transformar o mundo para pior...

Foi por essa época que comecei a dar aula, em regime de cooperação, no mestrado em ciência política da Universidade Federal de Pernambuco, para onde fui paulatinamente me mudando. Como e por quê? Mais uma vez, a sorte! Naqueles anos - início dos anos 90 do século que passou -, o mestrado em ciência política (hoje o bem sucedido Programa de Pós-Graduação em Ciência Política) estava para fechar as portas. Motivo: falta de doutores em número suficiente para atender às exigências da Capes. Sua nota estava lá embaixo e a própria reitoria da UFPE já pensava na possibilidade do fechamento. Seu coordenador era Robinson Cavalcanti - que tinha apenas o título de mestre. Como os que são daqui sabem, Robinson, um homem cristão e portanto emissário de paz, foi morto há cerca de dois anos de forma violenta e no contexto de uma tragédia familiar. Mas passemos.

Robinson me convidou - a mim e a um colega da Fundaj, também recém-doutor a nos integrarmos ao Programa, livrando-o assim da degola. Fomos. Foi então pela mão de Robinson Cavalcanti e pelos dons que eram seus, de diplomata sorridente e simpático, que, recém-chegado do doutorado no exterior e com um diploma novinho em folha, fui parar lá na Ciência Política, cumulando as novas funções de professor com minhas obrigações de pesquisador da Fundaj. E o Mestrado em Ciência Política foi salvo. Mas para não parecer bonzinho e angélico nesse meu relato de salvação daquele Programa, permitam-me aduzir que meu gesto não foi inteiramente desinteressado. Havia da parte de Robinson a promessa - feita a mim e ao colega que comigo foi - de que, assim que possível, seria feito um concurso para nos incorporar à Universidade. A promessa foi cumprida. Assim que surgiu a ocasião, fiz um concurso preparado à minha feição - mais uma sorte? - e mudei-me para lá, onde fiquei na ativa até o ano passado e onde, de certa forma, ainda me sinto estando até hoje.

Aqui sucedeu algo curioso. Desde que parti para fazer meu doutorado sobre direitos humanos e pensamento político de esquerda no Brasil, e depois, já de volta, com o fim virtual do nosso núcleo informal de sociologia jurídica no Departamento de Ciência Política da Fundaj, tinham praticamente cessado minhas ligações com a sociologia do direito. Até meus interesses intelectuais tinham mudado. Lembro que durante algum tempo, nesse período, dediquei minhas leituras a uma filósofa da política, Hannah Arendt, a ela levado pela descoberta, na França - onde fiz meu doutorado -, do olhar fenomenológico sobre o mundo e o fenômeno político. Praticamente nada mais tinha a ver com uma "sociologia de resultados" - aquela da minha pesquisa sobre os comissários e minha e de Affonso sobre os conflitos coletivos. E aí...

Ocorre que, mesmo tendo entrado na UFPE por meio e sob os auspícios da pós-graduação em ciência política, formalmente falando eu fiz um concurso para o Departamento de Ciências Sociais, o que obviamente implicava obrigações docentes que não se restringiam à pós-graduação. Ora, por uma série de razões que não vem ao caso detalhar, a disciplina sociologia jurídica, por ser sociologia, e mesmo sendo ministrada na Faculdade de Direito, era então assegurada pelo departamento onde tinha acabado de entrar. E aí, por força do meu passado - de minha formação em direito, de minhas ligações com Cláudio Souto e Joaquim Falcão, entre outros -, eis-me designado para ministrá-la. O que fiz a partir do ano letivo de 1994 até o ano passado, quando me aposentei. Voltei ao antigo aprisco. Como veem, 
a sorte continuava me perseguindo.

Foi no contexto dessa volta que voltei a antigas questões. O movimento "crítica do direito", por exemplo, tinha sido substituído, pelo menos em termos de denominação, pelo movimento do direito alternativo, muito ativo e professado naqueles anos. E aí, voltando a adotar o "desvio empiricista" de uma década antes, pus as unhas de fora e entrei no debate. Comecei por escrever um artigo bem simples - Ilegalidade e Direito Alternativo-, que teve uma audiência inesperada, mesmo por parte dos "alternativistas". Nele procurei exercitar um "bom-senso empírico" que via faltar nas formulações dos teóricos do direito alternativo. $\mathrm{Na}$ verdade, apesar das críticas que eles gostavam de fazer ao idealismo dos juristas tradicionais, que escreviam desconectados da realidade, eu acho que eles também eram idealistas. Estou utilizando essa palavra não no sentido corrente, que considera idealista aquele que tem um ideal (nesse sentido eu também sou um idealista), mas no seu sentido técnico, ligado à filosofia do conhecimento, que significa a interposição, entre o sujeito cognoscente e o objeto conhecido, de uma ideia normativa sobre a realidade.

Que ideia? A de que o povo, as classes populares são portadoras de uma concepção de justiça mais justa, igualitária e libertadora do que a concepção de justiça do direito oficial. Tenho minhas dúvidas. Não é que isso não possa acontecer. É que, em primeiro lugar, isso não ocorre necessariamente. $\mathrm{E}$, em segundo lugar, que isso não se aplica a todas as áreas da juridicidade. Reconheço, lógico, que algumas ações dos movimentos populares trazem consigo uma concepção desse tipo de direito mais justo. Por exemplo, as ações dos sem-terra, dos semteto e assim por diante. Essas ações são, até por definição, contra o direito de propriedade inscrito no Código Civil. E, até por razões estratégicas, coletivas. Mas isso não transforma os seus atores em coletivistas.

Acho que esses equívocos são em parte fruto de uma leitura muito idealista do "direito de Pasárgada" detectado por Boaventura Santos. Esse trabalho tornou-se uma espécie de paradigma do direito alternativo. Mas será que as pessoas leram-no direito? $\mathrm{O}$ "direito de Pasárgada" que emerge entre os favelados não é parte de um projeto de mudança da sociedade, é apenas uma estratégia de sobrevivência de pessoas pobres que, sem o título de propriedade do chão onde habitam e sem acesso ao judiciário oficial, inventam uma forma local de resolução dos conflitos ligados à posse da terra. E o direito que eles aplicam entre si reproduz, em linhas gerais, o direito oficial. E Boaventura diz isso. As pessoas compram e vendem os barracos, alugam, brigam por questões de vizinhança etc. Tudo mais ou menos igual ao que ocorre no mundo burguês circundante. Eu costumo dizer que os pobres são normais... ou seja: são como nós!

Aqui adentro rapidamente a questão do que seria um ensino jurídico crítico, tão recorrentemente reivindicado pelos alternativistas. $\mathrm{O}$ que seria esse ensino crítico? Um ensino para formar juristas que fossem críticos das iniquidades da nossa sociedade? Estou de acordo. Mas, nesse caso, lembro que não é só o jurista que deve ser crítico, também o economista, o médico etc. Agora, antes de tudo, o médico deve ser um bom médico, conhecer bem medicina, como o jurista deve antes de tudo conhecer bem o ordenamento jurídico, saber operá-lo com competência técnica.

Não, não se assustem, não virei um horroroso reacionário, embora até pareça, reconheço. $\mathrm{O}$ que estou querendo dizer é que não adianta, por exemplo, o camarada ser um advogado progressista e não saber fazer uma petição bem feita. Então, é basicamente para aprender "direito" direito, se me posso permitir o jogo de palavras, que o sujeito vem para uma faculdade de direito. Mas, na verdade, não é só isso que estou querendo dizer. Estou também pensando num nível, digamos assim, epistemológico. Eu tenho certas dúvidas a respeito do que seria um ensino crítico do direito. Ou, dizendo melhor, porque as duas coisas não são idênticas, tenho dúvidas sobre o que seria um direito crítico... Deixem-me explicar melhor.

Meu antigo orientador Joaquim Falcão colocou, certa feita, a seguinte questão (estou citando de memória): "se a medicina é uma ciência a favor da saúde, por que o direito não 
seria uma ciência a favor da justiça?” A frase é ótima. Mas acho que ela é problemática. Em primeiro lugar, a analogia não é perfeita porque a saúde e a justiça não estão num mesmo patamar de consenso. Estou querendo dizer o seguinte: todos nós sabemos o que é a saúde. $\mathrm{E}$ assim todos nós queremos a mesma coisa, correto? Mas a justiça, nós não sabemos direito o que é, e assim não queremos a mesma justiça. As sociedades democráticas, aliás, como diria outro mestre meu, Claude Lefort, alimentamse permanentemente do debate sobre o que é justo e o que não é. Então, nessas sociedades, a existência do conflito é legítima. $\mathrm{O}$ direito, aqui entendido como ordenamento jurídico, é apenas uma série de prescrições que dizem como, em determinado momento histórico, esses conflitos devem ser resolvidos. E ele próprio, por seu lado, está também sujeito permanentemente a esse debate, por isso está mudando o tempo todo, num movimento incessante e sem fim.

Ora, nessas condições, é difícil conceber o que seria o verdadeiro direito, o direito justo, um direito crítico da injustiça existente na sociedade e cuja aplicação estaria a cargo dos juristas formados num ensino diferente, crítico. Não apenas é teoricamente difícil conceber que prescrições conteria esse direito, como isso se chocaria com o princípio democrático da legitimidade do debate sobre o que é legítimo e o que não é. Raciocinemos em termos empíricos, como eu gosto de dizer. Como todos sabem, nós vivemos em sociedades divididas em classes. $\mathrm{E}$ a luta de classes está em toda parte. Muito bem. Mas como as sociedades em que vivemos não são apenas conflituosas, são também democráticas, as lutas de classes são, por assim dizer, legítimas. E o direito, entre outras coisas, é um instrumento de administração dessas lutas. Sejamos francos: o direito não existe para acabar com elas. Existe para administrá-las, isto é, domesticá-las.

Nesse caso, puxando o debate para o nível empírico, um conflito entre patrões e empregados que desemboque no judiciário vai exigir que as duas partes estejam representadas. Vai ter que ter o advogado dos explorados e o advogado dos exploradores. O primeiro pode, e aliás deve, ser um advogado "crítico". Mas e o segundo? Vai ser crítico também da ordem burguesa injusta? $\mathrm{Na}$ sua contestação vai dizer que o seu cliente é um explorador? Se fizer isso, o patrão o destituirá e chamará outro. Além disso, estará cometendo uma infração ao próprio ordenamento, o chamado "patrocínio infiel" - não é isso?

Isso dito, que fique bem clara uma coisa: do fato de que aceito de um modo geral a visão lefortiana da legitimidade dos conflitos nas sociedades democráticas, não se segue que considero (nem acho que Lefort considerasse, aliás) todos os conflitos, num mesmo momento histórico, igualmente legítimos. Dito de uma maneira mais precisa, que considero todas as pretensões em conflito igualmente empatadas em termos de justiça. Não! Todas as opiniões não se equivalem. De forma alguma passa pela minha cabeça tal relativismo. A sociedade não é um amontoado de mônadas soltas e de valores sem sentido, todos valendo a mesma coisa como se fossem marcas de sabonete num supermercado. Isso não é verdade. E não estou simplesmente expressando uma opinião pessoal. Quando digo que isso não é verdade, estou me referindo a um dado objetivo. Ou seja: objetivamente falando, não é verdade que todas as opiniões se equivalem porque existem certas coisas que as pessoas consideram mais certas do que outras, para falar de um modo bem simples. Como diria Cláudio Souto, não se pode chamar de direito aquilo que está errado. Existe, em alguma medida, hierarquia nos valores.

Imaginemos um conflito opondo camponeses miseráveis sem terra e o proprietário de uma fazenda improdutiva do tamanho da Bélgica, coisa que num país troncho como o Brasil é uma realidade. Eu não tenho dúvidas, e certamente a opinião pública brasileira também não tem, de que lado está a justiça. Mas, ainda aí, o nosso fazendeiro "belga" vaiter direitoa ser representado na justiça, não? E eu garanto que vai aparecer mais advogado interessado em patrocinar a sua causa do que a dos camponeses miseráveis... E esse não vai ser um advogado "crítico", vai ser dogmático, vai apelar para o que diz o Código Civil sobre a propriedade e seus modos de aquisição. Já o advogado dos camponeses vai ter de fazer uma construção teórica mais elaborada, vai ter de 
convencer o juiz de que o Código Civil tem de se adequar à Constituição que prevê a função social da propriedade etc. Voltando à minha exigência inicial, vai ter de ser um advogado competente. Em suma, também um bom dogmático! Bem, acho que é tempo de concluir.

Volto à pergunta inicial: $\mathrm{O}$ que sou? $\mathrm{Eu}$ fui apresentado e homenageado como sendo sociólogo do direito. O título até que me cabe, sem dúvida. Mas eu não tenho uma dedicação permanente à sociologia jurídica como tem um Cláudio Souto, um Joaquim Falcão, uma Miriam de Sá Pereira da Universidade Católica de Pernambuco, ou uma Eliane Junqueira do Rio de Janeiro. Hoje, entre nós, creio que meu querido Artur Stamford da Silva está percorrendo esse caminho. Eu, de minha parte, sempre fui um errático.

Li, certa vez, ou creio que li, um epigrama atribuído a Bernard Shaw segundo o qual "a celebridade é uma série de equívocos em torno de uma pessoa". Não que me ache (e, aliás, não sou) célebre. Mas, pelo menos nesta manhã estou curtindo esta fugaz celebridade que Artur, contando com a paciência de vocês, proporcionou-me. Mas me pergunto: até que ponto ela não tem um quê de equívoco? Juro que não estou sendo falsamente modesto - até porque toda modéstia é falsa. Estou pensando no que, em termos de sociologia jurídica, tenho feito nesses últimos vinte anos, desde que me tornei professor da disciplina nesta casa. Pensando numa sociologia jurídica de base empírica como entendo que deve ser -, é verdade que dei minha contribuição. Mas isso, rigorosamente falando, deu-se na primeira metade dos anos 80 do século que passou! De lá para cá, o que fiz que fosse uma verdadeira contribuição para o campo?

A última pesquisa de que participei com esse caráter, praticamente deixei-a pela metade. Foi no final dos anos 90. Por iniciativa de Eliane Junqueira, iniciamos uma enquete de caráter nacional sobre o ensino da sociologia jurídica no Brasil. Recolhidos mais de uma centena de questionários que amealhamos via postal entre professores da matéria, vi-me presa de um fastio tão grande diante daquele calhamaço que resolvi abandonar o barco. Eliane terminou fazendo sozinha a análise do material. Cheio de remorso, aceitei organizar com ela um seminário nacional na PUC-Rio, no ano de 2000, no qual talvez algum dos presentes tenha comparecido. E foi só.

Desde então, sobretudo nos últimos anos, terminei minha carreira dando aulas aqui nesta casa mais como uma obrigação do que como um prazer. Como tinha uma experiência acumulada, ligava o "piloto automático" e ficava esperando o fim do semestre. Lógico que não fiquei de braços cruzados todo esse tempo. Mas, como o errático que sou, fui sendo atraído por outros interesses (pensamento social brasileiro, por exemplo) e autores que, definitivamente, nunca foram sociólogos do direito: Claude Lefort, Hannah Arendt e, mais recentemente, Michel Foucault. Produzi e publiquei - até que bastante - e assumi cada vez mais minha vocação ensaística. O ensaio, afinal, permite-me, para citar outra vez Machado, "atar as duas pontas da vida".

Quero com isso dizer que, no fundo, talvez eu seja simplesmente um literato não realizado. É a volta ao meu primeiro amor - intelectualmente falando, obviamente -, aquele que a gente nunca esquece. Da mesma maneira que qualquer garoto que joga futebol sonha em ser Pelé, eu já sonhei em ser José de Alencar, Érico Veríssimo, Guimarães Rosa, Machado de Assis, mas também Graciliano Ramos. Acho que esse amor à literatura também me ajudou a matizar desde cedo meu marxismo. Eu me lembro de discussões intelectuais com meus amigos marxistas, na Aracaju da minha juventude, adeptos do chamado "realismo socialista", onde eu dizia, e não apenas para provocar, que Guimarães Rosa era o maior escritor brasileiro porque, como Deus, ele tinha criado um mundo que não existia antes da sua criação. E um "reacionário" como Machado de Assis? Com a maturidade, e agora às portas da velhice, minha admiração por ele só foi crescendo. Suas grandes obras, aquelas que vão de Memórias Póstumas de Brás Cubas a Memorial de Aires, escritas há mais de cem anos, não têm uma ruga! De vez em quando pego um desses livros e releio. O humor de Machado continua devastador. Meu amigo Fernando da 
Mota Lima, numa fórmula feliz, qualifica-o de "humor dissolvente". E Graciliano? Esse, sim, foi um Himalaia! Como explicar o milagre de um sujeito como ele, comerciante de tecidos em Palmeira dos Índios, interior das Alagoas, ter escrito no começo dos anos 30 do século que passou uma obra-prima irretocável como São Bernardo?... Paro por aqui.

A literatura foi e é importante na minha vida. Como literato frustrado, procuro sublimarme no que escrevo, procurando tanto quanto possível fugir do jargão acadêmico. Sempre que posso, dou uma pitadinha de sal literário aos meus textos. E confesso que às vezes não fico tão descontente com o resultado final...

Do fundo do coração, muito obrigado! 